\title{
AN EFFICIENCY REPORTING SYSTEM FOR ORGANISATIONAL SUSTAINABILITY BASED ON WORK STUDY TECHNIQUES
}

\author{
B. Sookdeo ${ }^{1 *}$
}

\section{ARTICLE INFO}

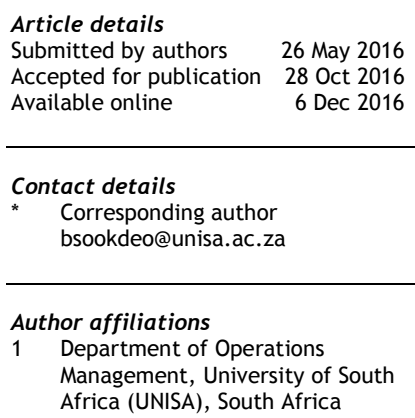

DOI

http://dx.doi.org/10.7166/27-4-1552

\section{ABSTRACT}

This article aims to demonstrate that work study techniques must be used to determine standard times for operations and to develop efficiency reporting systems to sustain organisations. Many organisations do not measure their efficiencies and do not have reporting systems. This article presents an efficiency reporting system designed and based on work study techniques that can be used to measure performance. The empirical results of the research instrument supported the need for the system. The existence of a dedicated efficiency reporting system ensures that employee performance and outputs in line with set targets are measured and sustained.

\section{OPSOMMING}

Hierdie artikel demonstreer dat werkstudietegnieke gebruik moet word om die standaard tye vir operasies te bepaal asook vir die ontwikkeling van doeltreffende rapporteringstelsels sodat organisasies volhoubaar kan wees. Baie organisasies meet nie hulle doeltreffendheid nie en het nie stelsels wat terugvoer akkommodeer nie. Hierdie artikel bied 'n doeltreffende rapporteringstelsel ontwerp aan wat gebaseer is op werkstudietegnieke wat gebruik kan word om prestasie te meet. Die empiriese resultate van die navorsingsinstrument bewys die noodsaaklikheid vir hierdie stelsel. Die bestaan van 'n doeltrefferede rapporteringstelsel verseker dat werknemer prestasie en uitsette gemeet en volgehou kan word volgens 'n stel voorafbepaalde teikens.

\section{1}

\section{INTRODUCTION}

In South Africa, about 40 per cent of new business ventures fail in their first year, 60 per cent in their second year, and 90 per cent in their first 10 years of existence [1]. About 75 per cent of small, micro, and medium enterprises do not become established businesses [2], and as many as 80 per cent fail in the first 10 years following inception. This trend cannot be allowed to continue, as the South African economy suffers due to the non-sustainability of organisations and subsequent job losses.

The major reason that organisations have trouble with manufacturing is the tendency for many managers to accept simplistic notions in evaluating the performance of their manufacturing facilities. The general tendency in many organisations is merely to evaluate manufacturing primarily on the basis of cost and efficiency. Pycraft, Singh, Philela, Slack, Chambers, and Johnston [3] state that a performance measure means relatively little until it is compared against some kind of target. Work study techniques can therefore be used to develop these targets. One of the main weaknesses of current performance management systems used by organisations is that they normally adopt a narrow, uni-dimensional focus. An organisation needs to beat its competition with superior operations using its people, assets, and technologies to compete more effectively in the marketplace. Despite these pressures, few organisations appear to have systematic processes in 
place to ensure that their performance measurement systems continue to reflect their environment and strategies [4].

This places organisations under tremendous pressure to reduce their costs, increase their service levels, and supply goods of superior quality to be sustainable and to challenge their competitors. In order to meet these goals and remain more competitive, organisations use many different tools, techniques, and strategies to make their production processes more efficient and, subsequently, to provide a quality output that satisfies the customer. Organisations are also always searching for ways to optimise business processes so that they can reduce manufacturing costs. Slack, Chambers, and Johnston [5] state that how management performs its activities can have a significant effect on an organisation. When standard times are unrealistic and unachievable, production schedules fail. Setting standard times for operations is not just a major challenge for today's work study officer it is critical. Some operations require high-cost, high-tech, traditional work measurement; but you can often employ a low-cost, low-tech method using the basics of work study.

The above information raises the question: 'Why measure?' This is pivotal to the author's decision to develop an efficiency reporting system, using work study techniques, as the goal of this paper. If organisations are to be competitive, they must understand that invisible value exists all around, awaiting discovery; efficiency reporting systems and controls allow them to 'see' this value. It must be understood that if you cannot measure, you cannot control, and that "if you cannot measure, you cannot manage" [6]. The primary purpose of this study is to use work study techniques to develop an efficiency reporting system that organisations can use to measure their outputs and thus their productivity. Riddle [7] states that increasing employee productivity should be at the forefront of any managerial mind. In simple terms, you must develop a statistical and measurable way to measure each employee's actual production, and then balance those numbers against the cost of each employee.

A tap manufacturing organisation was chosen for this study. Preliminary visits to the organisation revealed that their tap assembly department did not have properly-set standard times for their operational processes, some of which were highly labour-intensive. Daily production reports on performance to management were inconclusive in the absence of proper standard times; decisionmaking for achieving pre-determined goals was thus hindered. The current standard times for the operations were not compiled by experienced work study officers or an industrial engineering team. A standard time is the amount of time it should take a qualified worker to complete a specified task, working at a sustainable rate [8]. But when employees carry out work without set targets, there is no established method of measuring their outputs - that is, there is no recording system and no standard times.

The absence of scholarly articles on the use of work study techniques in developing monitoring systems gives credence to the essential contribution of this article. It ensures that organisations in South Africa have at their disposal a dedicated efficiency reporting system, developed using universally-accepted work study techniques, to measure and monitor their operational performance.

This article reports on the work study investigation that was conducted in the assembly department of the selected manufacturing organisation, and the use of the research instrument. This is preceded by a review of related literature, and followed by a discussion of the findings. The article concludes with the limitations of the study and suggestions for future research.

\section{LITERATURE REVIEW}

The central theme of this article is the emphasis on the use of work study techniques to develop an efficiency reporting system for organisational sustainability.

\subsection{Work study}

Work study is the systematic examination of the methods of carrying out activities to improve the effective use of resources and to set up standards of performance for the activities being carried out [9]. Sookdeo [10] states that work study succeeds because it is systematic, both in the investigation of the problem and in the development of its solution. Work study consists of two techniques - method study and work measurement - that are used to examine human work in all 
its contexts. This leads systematically to the investigation of all the factors that affect the efficiency and economy of the situations being reviewed, in order to effect improvements [3].

\subsubsection{Objectives of work study}

The primary objective of work study is to use its two techniques to improve productivity. It also assists management to obtain the optimum use of human and material resources available to the organisation to accomplish the work that has to be done. Seminal work by Currie [13] states that the objective of work study is to assist management to obtain the optimum use of the human and material resources available to an organisation, to accomplish the work on which it is engaged.

\subsubsection{Importance and value of work study}

Heizer and Render [14] state that little was known about what constituted a fair day's work, so managers initiated work study to improve work methods. The importance of work study as a management aid is being more widely recognised as organisations gear up to become more effective and efficient in their operations. In South Africa, organisations have already proved the importance of work study and related techniques in practice, and they continue to derive tremendous benefits from its implementation. The importance of work study can be summarised as the way to raise the productivity of an organisation by re-organising the work - a method that normally involves little or no capital expenditure on either facilities or equipment.

\subsubsection{Method study and work measurement techniques}

'Method study' can be defined as the systematic recording and examination of any type of work in order to develop a more efficient method of working and thereby to reduce costs. It eliminates unnecessary tasks and improves the process of completing tasks [10] [11].

'Work measurement' is the application of techniques designed to establish the time for a suitablyqualified worker to carry out a task at a defined rate of working [9]. Jacobs and Chase [12] state that the fundamental purpose of work measurement is to set time standards for a task. These two techniques of work study are in constant interaction, and aim eventually to improve the productivity of an organisation.

\subsection{Efficiency defined}

'Efficiency' means doing something at the lowest possible cost, and must not be confused with the term 'effectiveness', which means doing the right things to create the most value for the organisation. Efficiency is the ratio of the actual output of a single operator, line of operators, or group of lines (expressed in standard minutes produced) divided by attended minutes for the full duration that work has been carried out [15]. In order to avoid confusion, it is also important to separate the terms 'efficiency' and 'use', as an organisation's effectiveness is defined by these two measures [16]. 'Efficiency' can be likened to how well a machine or worker performs according to a set standard, while 'use' refers to the percentage of available working time that a worker actually works, or that a machine actually runs [17].

Stevenson [16] states that efficiency is the ratio of actual output to effective capacity:

Efficiency

$$
=\quad \frac{\text { Actual output }}{\text { Effective capacity }}
$$

The following example shows how to calculate operator efficiency:

One operator works eight hours in a day. The standard time to produce one unit is 3.5 standard minutes. The operator produces (output) 86 units during this period.

Therefore:

86 units $\times 3.5$ standard minutes $=301$ standard minutes

$301 /(8 \times 60) \times 100=62.71 \%$ operator efficiency

\section{RESEARCH METHODOLOGY}

\subsection{Research design}

A mixed-methods approach - that is, a mixture of both qualitative and quantitative research - was used for this study. Cresswell and Clark [18] state that, in mixed-methods research, the researcher combines elements of qualitative and quantitative research approaches for the purposes of breadth 
and depth of understanding. Research in this study took the form of systematic data collection relating to the requirements for the development of the efficiency reporting system. The theoretical concepts and the subsequent integration of the theory into the practice of the two techniques of work study represented the qualitative research of this study. The method study investigation involved using process charts to chart the activities of the present method of working, after which proposed/improved methods were developed. The work measurement investigation involved using time study to measure the duration of the activities.

\subsection{Research instrument}

The research instrument took the form of a questionnaire because the processes are highly labourintensive. The survey method was deemed appropriate, as respondents could easily be accessed, as reported by Alam, Hoque, Rout and Priyadarshani [19]. The questionnaire was compiled using the Lime-Survey program. It consisted mostly of Likert-scale type questions, and was used to gain insights into the development of efficiency reporting systems in organisations in South Africa. Data capturing and processing was an automatic process, and the author was assisted by a statistician based at the Bureau of Market Research at the University of South Africa (Unisa). A self-administered approach was followed, using a computer-aided web-based questionnaire. A dedicated uniform reference locator (URL) was established on the website of the Bureau of Market Research at Unisa. The e-mail message included a hyperlink to the URL where the questionnaire had been hosted. The respondents were invited by e-mail to go to the URL and complete the questionnaire online. The purpose of the questionnaire was to gather critical responses about the development and existence of efficiency reporting systems and measurement criteria of an organisation's manufacturing processes. It consisted of fifteen questions.

\subsection{Sample}

The target population consisted of selected employees $(n=800)$ of organisations in South Africa. Their positions ranged from operators and supervisory staff to management. Two hundred and thirty (230) respondents submitted their questionnaires online; all were considered suitable as they had completed 100 percent of the questions. The response rate was therefore 28.75 per cent and was deemed to be representative of the population.

\subsection{Data analysis and interpretation}

\subsubsection{Method study investigation}

Data collected from the method study investigation was analysed using the set procedure of the method study technique. Process charting was used to chart all the steps involved in the complete assembly of the tap. The present method of this assembly procedure was charted, and then improved to show a more effective and improved method (the proposed method). Thereafter, a comparison between the present and proposed methods was shown, including the savings that resulted from this investigation.

\subsubsection{Work measurement investigation}

The work measurement investigation consisted of time studies. It is vital to improve the method of working, as it is ineffective to set a standard time for an inefficient method of working. The recorded data of the time studies was analysed using the set procedure for this technique. Relaxation and contingency allowances were allocated and the standard times for each step of the assembly process were compiled. These standard times were then used to develop the efficiency reporting system.

\subsubsection{Questionnaire}

Descriptive analyses of all the questions were performed to look at the distribution of the respondents. The researcher then selected certain questions that were relevant to the outcome of this study and asked for cross-tabulations and chi-square tests to be performed. The aim was to see whether there were associations between the selected questions.

\section{RESULTS}

\subsection{Quantitative results}

\subsubsection{Method study investigation}

Flow process charts were compiled showing the complete assembly process of the tap. It consisted of seven steps. This meant that seven different operators assembled this tap on the assembly line. The seven steps were the following: Step 1: fit head part; Step 2: test water pressure; Step 3: fit 
back nut to tap (brass); Step 4: fit cover and handle; Step 5: fit indice (cold); Step 6: clean and polish; Step 7: package. The present and proposed flow process charts of Step 1 only are shown. Step 1 had 16 elements; each was described and a process chart symbol allocated to it (see Table 1). A summary of the different symbols for the present method was completed. Steps 1 , 4, and 7 were improved and a proposed method was compiled on a separate flow process chart (see Table 2). A new summary was completed showing the comparison between the present and proposed savings. A similar process was completed for the other six steps.

Table 1: Present method: Flow process chart: Step 1: Fit head part

\begin{tabular}{|c|c|c|c|c|c|}
\hline \multicolumn{6}{|c|}{ FLOW PROCESS CHART } \\
\hline \multirow{2}{*}{$\begin{array}{l}\text { LOCATION: } \\
\text { ACTIVITY: }\end{array}$} & \multirow{2}{*}{$\begin{array}{l}\text { Assembly Department } \\
\text { Assembly of tap }\end{array}$} & \multicolumn{4}{|c|}{ SUMMARY } \\
\hline & & EVENT & PRESENT & PROPOSED & SAVINGS \\
\hline $12-09-2015$ & $12-09-2015$ & Operation & 10 & & \\
\hline \multicolumn{2}{|r|}{ ANALYST: B. Sookdeo } & Transport & 4 & & \\
\hline \multicolumn{2}{|c|}{ METHOD AND TYPE: } & Delay & 1 & & \\
\hline \multirow{2}{*}{$\begin{array}{l}\text { METHOD: } \\
\text { TYPE: }\end{array}$} & \multirow{2}{*}{$\begin{array}{l}\text { Present } \\
\text { Operator }\end{array}$} & Storage & 0 & & \\
\hline & & Inspection & 1 & & \\
\hline \multirow{2}{*}{\multicolumn{2}{|c|}{$\begin{array}{l}\text { DESCRIPTION OF OPERATION: } \\
\text { Step 1: Fit head part }\end{array}$}} & Time (mins.) & 0 & & \\
\hline & & $\begin{array}{l}\text { Distance } \\
\text { (matracl }\end{array}$ & 100 & & \\
\hline STEP NO. & $\begin{array}{l}\text { DESCRIPTION } \\
\text { OF ELEMENTS }\end{array}$ & SYMBOL & $\begin{array}{c}\text { TIME } \\
\text { (minutes) }\end{array}$ & $\begin{array}{c}\text { DISTANCE } \\
\text { (metres) }\end{array}$ & REMARKS \\
\hline$\overline{1}$ & Prepare workplace & & $\Rightarrow$ & & \\
\hline 2 & Fetch jig from store & & & 40 & \\
\hline 3 & Position at workplace & & 7 & & \\
\hline 4 & $\begin{array}{l}\text { Fetch head parts from } \\
\text { storage }\end{array}$ & & $\Rightarrow$ & 10 & \\
\hline 5 & Position at workplace & & & & \\
\hline 6 & $\begin{array}{l}\text { Fetch body parts from } \\
\text { storage }\end{array}$ & & & 10 & \\
\hline 7 & Position at workplace & & $\Rightarrow$ & & \\
\hline 8 & $\begin{array}{l}\text { Wait for other stations to } \\
\text { set up }\end{array}$ & & $\Rightarrow$ & & \\
\hline 9 & $\begin{array}{l}\text { Pick up body part and } \\
\text { pos. in jig }\end{array}$ & & $\Rightarrow$ & & \\
\hline 10 & $\begin{array}{l}\text { Pick up head part and } \\
\text { pos. in body }\end{array}$ & & $\Rightarrow \nabla$ & & \\
\hline 11 & Screw on head part & & $\Rightarrow \nabla$ & & \\
\hline 12 & $\begin{array}{l}\text { Pick up assembled head } \\
\text { part }\end{array}$ & & $\Rightarrow \nabla$ & & \\
\hline 13 & Inspect head part & & $\Rightarrow \square$ & & \\
\hline 14 & $\begin{array}{l}\text { Place head part onto } \\
\text { conveyor }\end{array}$ & & $\Rightarrow \nabla$ & & \\
\hline 15 & $\begin{array}{l}\text { Remove and aside empty } \\
\text { boxes }\end{array}$ & & 7 & & \\
\hline 16 & Take jig back to store & & $\nabla$ & 40 & \\
\hline
\end{tabular}


Table 2: Proposed method: Flow process chart: Step 1: Fit head part

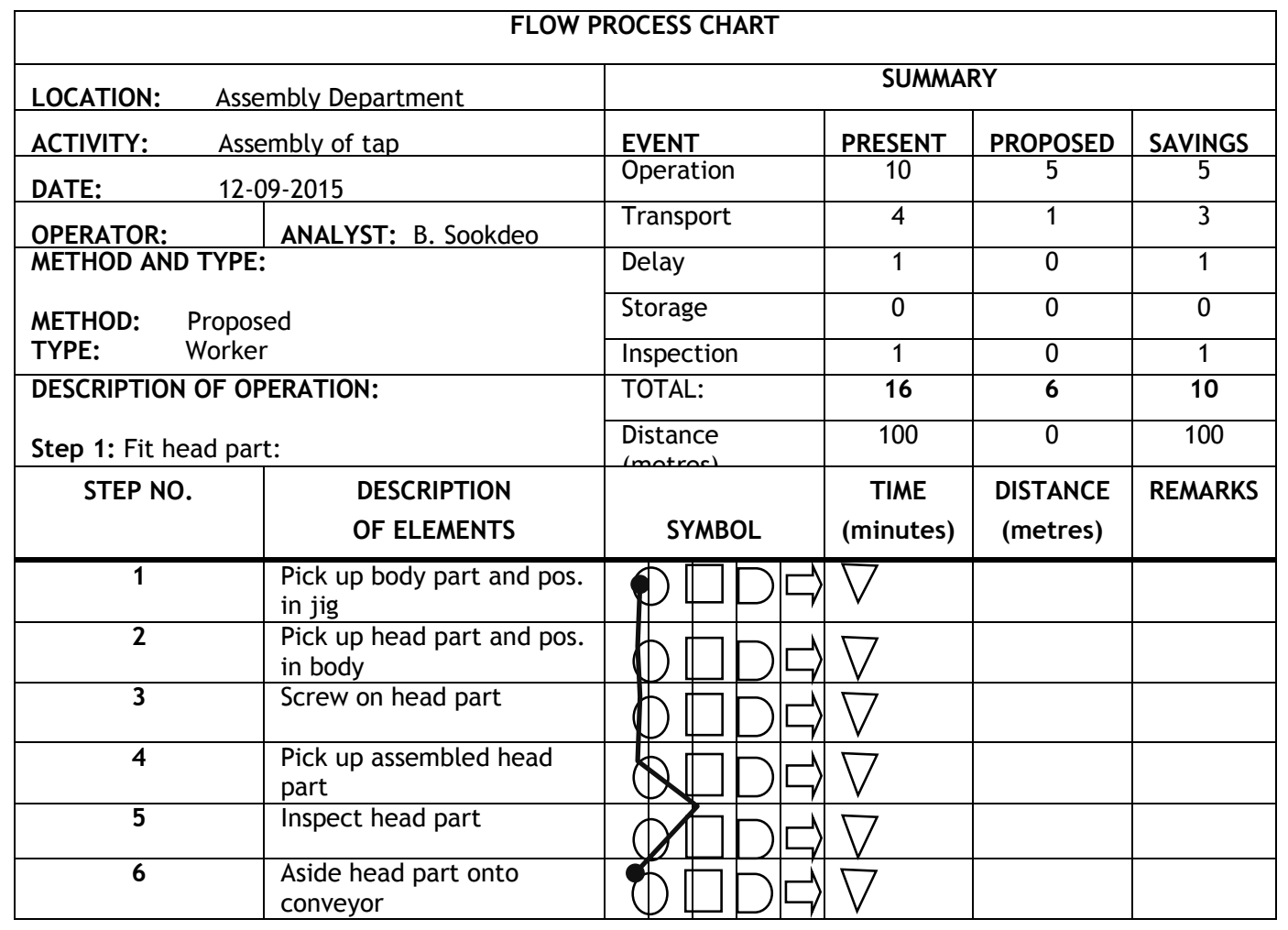

The rationale for the savings in Step 1 is as follows:

Note that steps 1 to 8 and 15 and 16 have been eliminated in Table 2 because these ten elements will be conducted as 'inside work'. Kanawaty [9] states that inside work comprises those elements that can be performed by a worker within the machine (or process) controlled time. This means that all the preparatory elements leading up to Step 1 must be conducted before Step 1 starts. Hence, the time that it takes to complete Step 1 is significantly minimised. A savings of 100 metres in distance travelled was also realised.

\subsubsection{Work measurement investigation}

The duration of the seven steps of the tap assembly was determined by conducting time studies. The average basic times for each step were calculated and used to compile the standard time for assembling the tap. Hence, as an example, the first observation showed a rating of 80 and an observed time of 0.177 centiminutes. The formula to calculate the basic time for observation 1 is:

Basic time $=\frac{\text { Rating } \mathrm{x} \text { observed time }}{\text { Standard rating }(100)}=\frac{80 \times 0.177}{100}=0.150$ centiminutes

Table 3 shows the method used to calculate the standard time for the complete assembly of the tap. A rest allowance of 12 per cent and a contingency allowance of four per cent were applied. The rest allowance is an addition to the selected basic time, giving the worker the opportunity to recover from the physiological and psychological effects of carrying out work; the contingency allowance is a small allowance of time that may be added to the total actual time to account for unexpected items of work or delays due to their occasional occurrence [9]. 
Table 3: Calculation of the standard time for the assembly process

\begin{tabular}{|c|c|c|c|c|c|c|}
\hline \multicolumn{7}{|c|}{ STANDARD TIME CALCULATION } \\
\hline $\begin{array}{l}\text { Step } \\
\text { No. }\end{array}$ & $\begin{array}{c}\text { Element } \\
\text { description }\end{array}$ & $\begin{array}{l}\text { Basic } \\
\text { time }\end{array}$ & Frequency & $\begin{array}{c}\text { Selected } \\
\text { basic time }\end{array}$ & $\begin{array}{c}\text { Rest } \\
\text { allowance }\end{array}$ & $\begin{array}{l}\text { Actual } \\
\text { time }\end{array}$ \\
\hline 1 & Fit head part & 0.153 & $1 / 1$ & 0.153 & 12 & 0.171 \\
\hline 2 & Test water pressure & 0.154 & $1 / 1$ & 0.154 & 12 & 0.172 \\
\hline 3 & Fit back nut to tap & 0.103 & $1 / 1$ & 0.103 & 12 & 0.115 \\
\hline 4 & Fit cover and handle & 0.096 & $1 / 1$ & 0.096 & 12 & 0.107 \\
\hline 5 & Fit indice (cold) & 0.129 & $1 / 1$ & 0.129 & 12 & 0.144 \\
\hline 6 & Clean and polish & 0.101 & $1 / 1$ & 0.101 & 12 & 0.113 \\
\hline 7 & Package & 0.069 & $1 / 1$ & 0.069 & 12 & 0.077 \\
\hline \multicolumn{6}{|c|}{ Total actual time: } & 0.899 \\
\hline \multicolumn{6}{|c|}{ Contingency allowance: $4 \%$} & 0.036 \\
\hline \multicolumn{6}{|c|}{ STANDARD TIME: (centiminutes) } & 0.935 \\
\hline
\end{tabular}

\subsubsection{The efficiency reporting system}

The methodology used to design and develop the efficiency reporting system as the output of this study is presented below. Note that the standard time to assemble only one product (tap) was used in the efficiency reporting system. Under normal circumstances, there could be a variety of products, and a separate standard time would need to be developed for each product. Therefore, irrespective of the number of products being produced or manufactured by any organisation, the same principle of determining standard times will apply.

Actual output per hour: =

Actual time per item: $\quad=$

Cumulative actual time: $=$

Standard time: $\quad=$

Efficiency per hour (\%) =

Average percentage per day
54 (number of taps assembled in $1^{\text {st }}$ hour: 08:00 to 09:00)

1.111 (60 minutes per hour / 54 (actual output per hour))

1.111 (Therefore: 08:00 to 09:00 $=1.111+1.395$ )

0.935 (calculated standard time for assembly of tap)

$0.935 / 1.111 \times 100$

$\underline{84 \%}$

Total for 8 hours $/ 8$

612 / 8

76.50\%

Table 4: Efficiency reporting system

\begin{tabular}{|c|c|c|c|c|c|c|c|c|}
\hline \multicolumn{9}{|c|}{ DEPARTMENT: TAP ASSEMBLY } \\
\hline LINE NO. 01 & \multicolumn{2}{|c|}{ Description: Tap 1} & \multicolumn{2}{|c|}{ Date: $13 / 10 / 2015$} & \multicolumn{4}{|c|}{ Captured by: B. Sookdeo } \\
\hline TIME: & $\begin{array}{c}08: 00 \\
\text { to } \\
09: 00\end{array}$ & $\begin{array}{c}09: 00 \\
\text { to } \\
10: 00\end{array}$ & $\begin{array}{c}10: 00 \\
\text { to } \\
11: 00\end{array}$ & $\begin{array}{c}11: 00 \\
\text { to } \\
12: 00\end{array}$ & $\begin{array}{c}12: 00 \\
\text { to } \\
13: 00\end{array}$ & $\begin{array}{c}13: 00 \\
\text { to } \\
14: 00\end{array}$ & $\begin{array}{c}14: 00 \\
\text { to } \\
15: 00\end{array}$ & $\begin{array}{c}15: 00 \\
\text { to } \\
16: 00\end{array}$ \\
\hline $\begin{array}{l}\text { Actual output } \\
\text { per hour }\end{array}$ & 54 & 43 & 59 & 33 & 40 & 58 & 56 & 51 \\
\hline $\begin{array}{l}\text { Actual time } \\
\text { per item }\end{array}$ & 1.111 & 1.395 & 1.017 & 1.818 & 1.500 & 1.034 & 1.071 & 1.186 \\
\hline $\begin{array}{l}\text { Cumulative } \\
\text { actual time }\end{array}$ & 1.111 & 2.506 & 3.523 & 5.342 & 6.842 & 7.876 & 8.948 & 10.124 \\
\hline $\begin{array}{l}\text { Standard } \\
\text { time }\end{array}$ & 0.935 & 0.935 & 0.935 & 0.935 & 0.935 & 0.935 & 0.935 & 0.935 \\
\hline $\begin{array}{l}\text { Cumulative } \\
\text { standard time }\end{array}$ & 0.935 & 1.870 & 2.805 & 3.740 & 4.675 & 5.610 & 6.545 & 7.480 \\
\hline $\begin{array}{l}\text { Efficiency per } \\
\text { hour (\%) }\end{array}$ & $84 \%$ & $67 \%$ & $92 \%$ & $51 \%$ & $62 \%$ & $90 \%$ & $87 \%$ & $79 \%$ \\
\hline \multicolumn{8}{|c|}{ Average percentage per dav: } & $76.5 \%$ \\
\hline
\end{tabular}


The efficiency reporting system allows the production clerk to input only the number of units (taps) produced for the hour worked. All other information is protected in the spread sheet. Upon this input, the efficiency reporting system generates the efficiency for that particular hour, as the standard time for this tap is linked to the hour under review. The efficiency reporting system also generates a graph (Figure 1) showing the performance of each assembly line on an hourly basis.

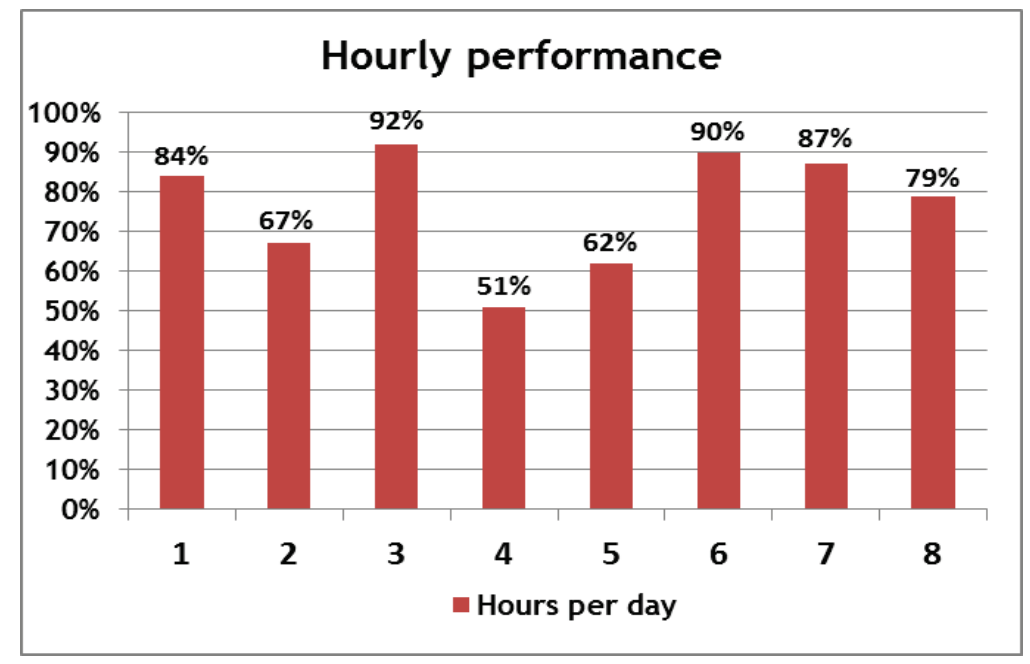

Figure 1: Hourly performance of Line 1

\subsection{Qualitative results}

Only significant responses related to the existence of efficiency reporting systems and the methodology for its development are reported on. Descriptive analyses were performed to look at the distribution of the respondents.

\subsubsection{Standard times}

Standard times are critical to measuring production outputs. They need to be realistic and achievable, and so need to be compiled by qualified personnel. Only 23.5 per cent of respondents indicated that their production targets were set by work study/industrial engineering. This indicates that a very large number of organisations had neither proper standard times nor monitoring systems for their processes. This was alarming, as it leads to inaccurate production reporting, affects management decision-making, and can disadvantage employees in the workplace.

\subsubsection{The efficiency reporting system}

The following explains the survey results of the efficiency reporting system. Respondents were requested to indicate whether their organisations currently had an efficiency reporting system in place. A total of 78.9 per cent of respondents indicated that their organisations did have an efficiency reporting system. The quality of the system comes into question, as this contradicts the 23.5 per cent of respondents who indicated that their production targets were set using work study. Also, only 28.3 per cent of the respondents indicated that they monitored their production via an efficiency reporting system. This provided justification for the need for efficiency reporting systems in organisations. Respondents were also requested to indicate the purposes for which the calculated efficiencies were used. Options differed from "Discussed at production meetings" to "Staff are notified of the results". The respondents indicated that the efficiency results were discussed at production meetings and were also used to undertake corrective action. A total of 46.7 per cent indicated that the results were used to show the performance of the department. It was evident that the efficiency reporting system was beneficial to their organisations.

\section{5}

\section{CONCLUSIONS AND RECOMMENDATIONS}

Organisations in South Africa are affected annually by labour unrest, with employees constantly demanding increased remuneration. 'Strike season' seems to have become a norm in the South African calendar year. The author is of the opinion that an increase in remuneration must be combined with a simultaneous increase in productivity to allow for a 'win-win' situation between 
the employer and employee. The literature review identified the absence of efficiency reporting systems in organisations as the main cause for concern. The research instrument supported this, as only 23.5 per cent of the respondents indicated that their production targets were set by work study/industrial engineering. This confirmed the need for efficiency reporting systems to be developed using work study techniques. The results indicated that organisations are failing to do this, which inevitably leads to low outputs, which in turn lead to low sales revenue and subsequently to low profits.

The results of this study provide some important insights into the field of work study. It explains the methodology to be used to implement its two techniques to improve the method of working and to compile standard times for developing the efficiency reporting system. The article succeeds in providing an answer to the research question: Why measure? Performance measurement is critical to organisational effectiveness and sustainability, and, as the saying goes: What you cannot measure, you cannot manage. The findings of this study will add value to organisations that do not measure their performance regularly, and especially to those that need to effect productivity improvements.

This article makes an essential contribution, as the work study investigation and the efficiency reporting system add to the body of knowledge in the fields of 'work study', 'management services', and 'quality and operations management'. The efficiency reporting system was tested at a large manufacturing organisation, adapted to their needs, and subsequently implemented. It is recommended that manufacturing organisations use this efficiency reporting system and adapt it to their specific needs. They should also make every attempt to measure their efficiencies hourly. This leads to the early detection of non-conformances in their production processes, and subsequent corrective action. Supervisors will be able to monitor progress continuously.

The study on which this article reports is limited to the assembly of taps only. Work study is not restricted to the manufacturing sector and, as future research, it would be useful to extend this efficiency reporting system to service industries as well; work study can be applied anywhere that work is performed.

Van Scheers and Radipere [20] sum up the value of this article with this statement:

"Performance measurement allows organisations to determine whether they can remain profitable and sustainable, as the sustainability of organisations is considered to be the panacea for South Africa's unemployment problems and a stagnating economy".

\section{REFERENCES}

[1] CSS [Central Statistical Service]. 2002. Development of SMMEs. Available at http:/ /www.statssa.gov.za/Statisticalreleases.html. (Accessed 30 March 2013)

[2] Fatoki, O. and Garwe, D. 2010. Obstacles to the growth of new SMEs in South Africa: A principal component analysis approach, South African Journal of Business Management, 4(5), pp. 729-738.

[3] Pycraft, M., Singh, H., Philela, K., Slack, N., Chambers, S. and Johnston, R. 2010. Operations management: Global and South African perspectives, $2^{\text {nd }}$ edition. Cape Town: Pearson Education.

[4] Patton, S., Clegg, B., Hsuan, J. and Pilkington, A. 2011. Operations management. New York: McGrawHill.

[5] Slack, N., Chambers, S. and Johnston, R. 2010. Operations management. $6^{\text {th }}$ edition. Upper Saddle River: Prentice Hall / Pearson Education.

[6] Rollins, S.C. and Lanza, R.B. 2005. Essential project investment and governance and reporting. Boca Raton: J. Ross Publishing.

[7] Riddle, J. 2010. The manager's guide to increasing employee productivity. Workawesome.com. (Accessed 30 March 2013)

[8] Stevenson, W.J. 2012. Operations management: Theory and practice. $11^{\text {th }}$ edition, Global edition. New York: McGraw-Hill.

[9] Kanawaty, G. 1995. Introduction to work study. $4^{\text {th }}$ revised edition. Geneva: International Labour Office.

[10] Sookdeo, B. 2012. Method study. $1^{\text {st }}$ Edition. Pretoria: Unisa Press. CIWSO1E/1/2012. InDesign. Florida.

[11] Reid, D.R. and Sanders, N.R. 2013. Operations management. $5^{\text {th }}$ edition. Hoboken: John Wiley and Sons.

[12] Jacobs, F.R. and Chase, R.B. 2011. Operations and supply chain management. Global edition. $13^{\text {th }}$ edition. New York: McGraw-Hill.

[13] Currie, R.M. 1981. Work-study. $4^{\text {th }}$ edition. London: Pitman Books.

[14] Heizer J. and Render B. 2014. Operations management. $11^{\text {th }}$ edition. Upper Saddle River: Pearson Prentice Hall. 
[15] Chase, R.B, Jacobs, F.R. and Aquilano, N.J. 2006. Operations management for competitive advantage with global cases. $11^{\text {th }}$ edition. New York: McGraw-Hill.

[16] Stevenson, W.J. 2007. Operations management. $9^{\text {th }}$ edition. New York: McGraw-Hill.

[17] Russell, R.S. and Taylor, B.W. 2009. Operations management: Along the supply chain. Hoboken: John Wiley and Sons.

[18] Cresswell, J.W. and Clark, V.L. 2011. Designing and conducting mixed-methods research. $2^{\text {nd }}$ edition. Thousand Oaks: Sage.

[19] Alam, G.M., Hoque K.E., Rout G.K. and Priyadarshani, N. 2010. State business of education or private higher education business in developing nations? A study to understand the policy impact in Bangladesh, African Journal of Business Management, 4(5), pp. 770-789.

[20] Van Scheers, L. and Radipere, S. 2007. Why are so many managers not "managing"? African Journal of Business Management, 5(8), pp. 85-91. 